\title{
latrogenic perforation of subclavian artery as a complication of coronary angiography from the radial route, endovascularly repaired with a covered stent-graft
}

\author{
Muhammad Ali Abdool, Siobhan Morrison, Heather Sullivan
}

Aintree Cardiac Centre, Aintree University Hospital NHS Foundation Trust, Liverpool, UK

\section{Correspondence to} Dr Muhammad Ali Abdool, Aintree Cardiac Centre, Aintree University Hospital NHS Foundation Trust, Liverpool, UK:

ali.abdool@aintree.nhs.uk
To cite: Abdool MA Morrison S, Sullivan H. BMJ Case Reports Published online: Published online: [please include Day Month Year] doi:10.1136/bcr-2012007602

\section{DESCRIPTION}

This 86-year-old, independent and mobile lady with a previous coronary artery bypass and bioprosthetic aortic valve replacement was admitted with angina and ventricular tachycardia. She proceeded to have an uneventful coronary angiogram with graft study from the right radial approach. Thirty minutes postprocedure, she experienced central chest and epigastric pain radiating into the back, developed stridor and became hypotensive. She was treated for the common periprocedural complications of anaphylactic reaction to contrast and infection. ${ }^{1}$ Her chest radiograph, an hour later, demonstrated a widened mediastinum with bilateral pleural effusions. Two hours later, a thoracic CT scan (figure 1) demonstrated a mediastinal haematoma displacing the trachea and oesophagus. Immediate CT angiography (figure 2) confirmed extravasation of contrast from the posterior aspect of a tortuous right subclavian artery.

The perforation was managed conservatively for $12 \mathrm{~h}$, but her ongoing requirement for multiple blood transfusions required input from the vascular surgeons. Nineteen hours after the perforation, they inserted a Gore VIABAHN $8 \mathrm{~mm} \times 50 \mathrm{~mm}$ covered stent-graft (figure 3 ) from the right femoral route into the right subclavian artery. This stabilised her condition and she made an uneventful recovery to her preadmission functional state

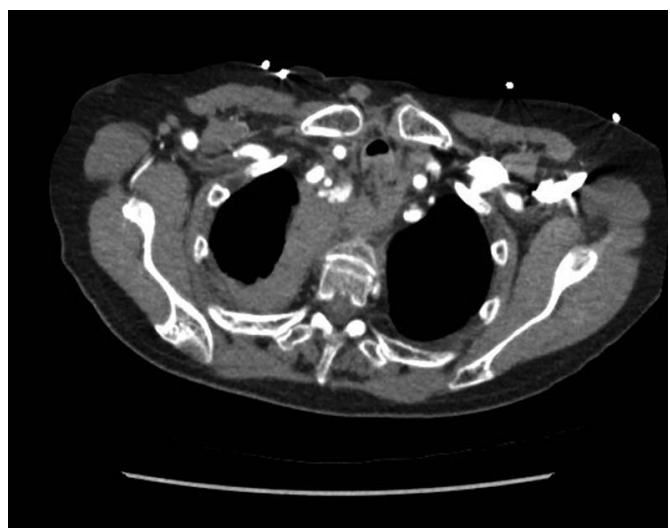

Figure 1 Thoracic CT scan showing high-attenuation haemorrhage/haematoma in the mediastinum displacing the oesophagus and trachea to the left side.

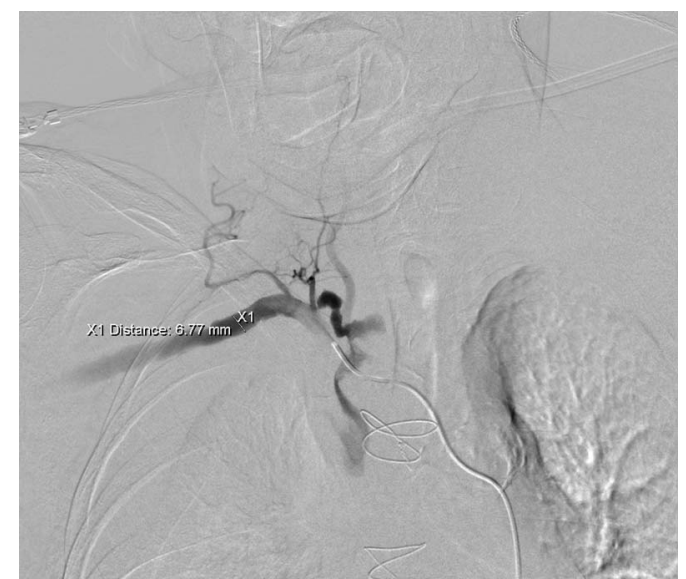

Figure 2 Digital substraction CT angiography showing contrast leak from $\mathrm{R}$ subclavian artery.

over the next 2 weeks, with conservative medical management of her index cardiac presentation.

There has been one similar case report published previously, ${ }^{2}$ which indicates that such a complication, whilst rare, is possible. Endovascular treatment for vascular trauma has been shown to have a $96.9 \%$ success rate for stent placement and $84.4 \%$ follow-up stent patency. ${ }^{3}$

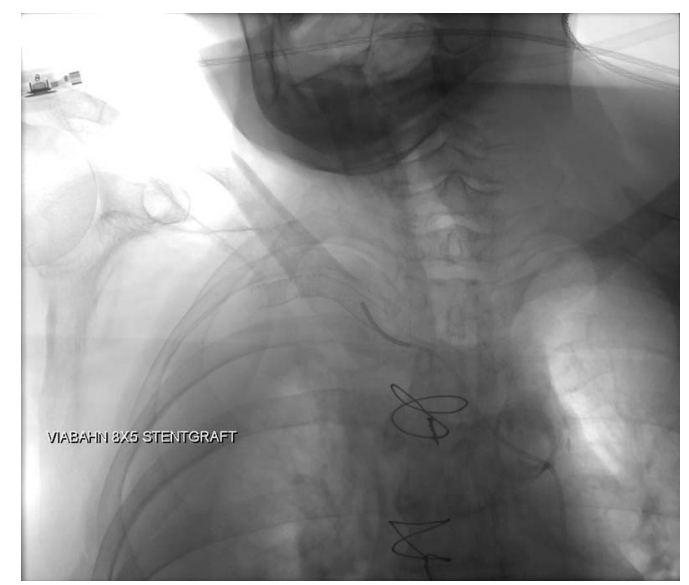

Figure 3 Angiogram showing placement of Gore VIABAHN $8 \mathrm{~mm} \times 5 \mathrm{~cm}$ covered stent-graft. 


\section{Learning points}

- Although coronary angiography is relatively safe, postprocedure observation by qualified personnel with on-site high-dependency care is essential.

- Timely basic resuscitation is vital in the early stages of managing acute, life-threatening haemorrhage with more definitive, expert management delayed until the patient is stabilised.

- Simple investigations can identify most coronary angiographic complications, even the rarest ones.
Competing interests None.

Patient consent Obtained.

Provenance and peer review Not commissioned; externally peer reviewed.

\section{REFERENCES}

1 Tavakol M, Ashraf S, Brener SJ. Risks and complications of coronary angiography: a comprehensive review. Global J Health Sci 2011;4:65-93.

2 Habib N, Jerzewski a, Koomen EM, et al. Subclavian artery perforation complicating coronary angiography. Neth Heart J 2012;20:288-90.

3 Dubose JJ, Rajani R, Gilani R, et al. Endovascular management of axillo-subclavian arterial injury: a review of published experience. Injury 2012;43:1785-92.

Copyright 2013 BMJ Publishing Group. All rights reserved. For permission to reuse any of this content visit http://group.bmj.com/group/rights-licensing/permissions.

BMJ Case Report Fellows may re-use this article for personal use and teaching without any further permission.

Become a Fellow of BMJ Case Reports today and you can:

- Submit as many cases as you like

- Enjoy fast sympathetic peer review and rapid publication of accepted articles

- Access all the published articles

- Re-use any of the published material for personal use and teaching without further permission

For information on Institutional Fellowships contact consortiasales@bmjgroup.com

Visit casereports.bmj.com for more articles like this and to become a Fellow 